\title{
Evaluation of the characteristics of vineyard pruning residues for energy applications: effect of different copper-based treatments
}

\author{
Daniele Duca, Giuseppe Toscano, Andrea Pizzi, Giorgio Rossini, Sara Fabrizi, Giulia \\ Lucesoli, Andrea Servili, Valeria Mancini, Gianfranco Romanazzi, Chiara Mengarelli \\ Department of Agricultural, Food and Environmental Sciences, Marche Polytechnic University, \\ Ancona, Italy
}

\begin{abstract}
The role of biomass for increasing renewable energy sources mix is considered fundamental, despite some negative environmental impact of first-generation biofuels. The use of biomass obtained in a more sustainable way, as represented by agricultural wastes, should be favoured. The Mediterranean area and Italy in particular offer a large amount of vineyard pruning residues that can be converted into bioenergy. Since vineyards are exposed to treatments based on copper $(\mathrm{Cu})$ and zinc, these metals last in wood residues during pruning and accumulate in the soil. In this study an evaluation of the concentrations of copper and other heavy metals in grapevine pruning wastes, when treated with common plant protection products, was carried out. The study was also extended to the soil, being potentially mixed to the biomass in the case of mechanical collection of pruning residues. The grapevine residues free of impurities that were collected during this study have typical values of copper in pruning wood, varying from $8.5 \mathrm{mg} \mathrm{kg}^{-1}$ when treated with low $\mathrm{Cu}$ product, to $19.2 \mathrm{mg} \mathrm{kg}^{-1}$ when treated with high $\mathrm{Cu}$ product. It was observed that contaminations during pruning with soil could increase the amount of copper in the residues. More in detail, every percentage point of soil that winds up on pruning residues involves an increase of 1 $\mathrm{mg}$ of $\mathrm{Cu}$ every kg of biomass. For this reason, we recommend the use of appropriate systems for the harvest of grapevine residues, particularly mechanical systems that avoid soil lifting. Moreover, we suggest the use of pruning residues preferably in large-scale power plants with appropriate emission filters instead of small-scale domestic boilers.
\end{abstract}

Correspondence: Daniele Duca, Department of Agricultural, Food and Environmental Sciences, Marche Polytechnic University, via Brecce Bianche, 60131 Ancona, Italy.

Tel.: +39.071.2204297 - Fax: +39.071 .2204167 .

E-mail: d.duca@univpm.it

Key words: Grapevine residues; copper; characterisation; mechanical harvesting; energy application.

Received for publication: 13 July 2015.

Accepted for publication: 21 September 2015.

(C) Copyright D. Duca et al., 2016

Licensee PAGEPress, Italy

Journal of Agricultural Engineering 2016; XLVII:497

doi:10.4081/jae.2016.497

This article is distributed under the terms of the Creative Commons Attribution Noncommercial License (by-nc 4.0) which permits any noncommercial use, distribution, and reproduction in any medium, provided the original author(s) and source are credited.

\section{Introduction}

As indicated in the Renewable Energy Directive (RED) 2009/28/EC on the promotion of renewable energy sources, in the European Union the share of renewable energy in gross final energy consumption should move from $8.5 \%$ (in 2005) to $20 \%$ by 2020 (European Commission, 2009). Therefore, National Renewable Energy Action Plans (NREAPs) established in 2012 by the EU Member States (European Commission, 2014) expected the share of Renewable Energy Sources (RES) in the gross final energy consumption in the EU to overcome the $11.6 \%$ of 2010 and reach $20.7 \%$ in 2020 . In particular, the total contribution of energy from biomass to the RES mix, representing almost $45 \%$ of RES mix, is expected to increase from about 3000 Petajoules (PJ) in 2010 to about $4600 \mathrm{PJ}$ in 2020 (Szabò et al., 2011).

In this context, the role of biomass for increasing RES mix appears to be fundamental even though some negative environmental impact of first-generation biofuels are under discussion: land use changes and damage to biodiversity, impact on food availability and real greenhouse gas emission reduction (Doornbosch and Steenblik, 2007; Gallagher, 2008; Searchinger et al., 2008). From this point of view, the use of biomass obtained in a more sustainable way, as represented by agricultural residues, agro-industrial residues and wastes should be favoured. Due to their benefits many studies focused on the agricultural and agro-industrial residues potential for energy production in EU (Koukios, 1998; Diamantidis and Koukios, 2000; Nikolaou et al., 2003; De Noord et al., 2004; Siemons et al., 2004; Ericsson and Nilsson, 2006; Bacenetti et al., 2015), highlighting the great importance for their energetic utilisation. More in detail, considering the EU-27, the total bioenergy potential of agricultural crop residues (straw from cereals, stalks from maize, rapeseed and sunflower, vineyard and olive trees pruning) is estimated to consist in 1370 PJ EU-27 (Monforti et al., 2013).

Among different kind of crop residues, the Mediterranean area and Italy in particular offer a large amount of vineyard pruning residues. In 2011, almost 3218.5 kha were cultivated with vineyards in Europe (EUROSTAT, 2014) and 725.1 kha in Italy (ISTAT, 2014). Referring to these data and considering appropriate production indexes evaluated by the Italian National Agency for New Technologies, Energy and Sustainable Economic Development (Motola et al., 2009) it is possible to estimate about 1400 kt dry matter of potential residues deriving from vine cultivation.

The energetic use in this case is particularly recommended because pruning residues are not an income source for farmers but in most situations, a cost. The disposal of vineyard residues usually consists in shredding and burying them or burning them. Nevertheless, both solutions have negative implications: the laying of residues underground has positive consequences in case of healthy vineyard but not for a vineyard 
damaged by trunk disease pathogens because of increased inoculum. The burning of residues has environmental implications both for emissions in atmosphere and fire risk. The National decree 22/97 indicates that pruning residues become waste if disposed elsewhere, with a consequent cost of disposal (Italian Regulation, 1997). Instead, in the case of an energetic use, as stated in National decree 152/06, they can be considered biofuels (Italian Regulation, 2006). They are also indicated as biofuels in the technical standard ISO 17225-1:2014 (ISO, 2014). For this reason, vineyardpruning residues can be used in the form of chips or pellets for the combustion in small, medium and large size boilers. Currently some vineyard pruning residues are employed in power plants (>1 MWel) in addition to other biomasses. However, the common management of grapevine, mostly in organic agriculture, implies the use of plant protection products using copper $(\mathrm{Cu})$ as active ingredient, together with other fungicides that can contain heavy metals (e.g., zinc, Zn) (Romanazzi et al., 2014). Many studies have investigated about the movement of $\mathrm{Cu}^{2+}$ into the vine plant after usual treatments (Romeu-Moreno et al., 1999; Lai et al., 2010; Provenzano et al., 2010; Juang et al., 2012) and its solubility within the soil (Ribolzi et al., 2002; Komárek et al., 2010; Ruyters et al., 2013). Another study has dealt with the $\mathrm{Cu}$ content in wine production residues (Toscano et al., 2013). The heavy metals contained in pesticides last partially on the surface of vines, and also on the pruning residues, causing the emission of pollutants in flue gas or ash during combustion in boilers (Obernberger et al., 2006; Picchi et al., 2013). This phenomenon arises particularly with small-scale domestic boilers, generally not equipped with flue gases abatement systems (Mc Donald, 2000).

In this context, the present study aims at evaluating the concentrations of copper and other heavy metals in grapevine pruning residues when treated with common plant protection products to better evaluate their suitability for an energetic application. The study was performed soon after the pruning collection and extended to the soil, being potentially mixed to the biomass in the case of mechanical collection of pruning residues.

\section{Materials and methods}

The grapevine pruning wood was collected in March 2014 from a 6year-old vineyard. Usually in this period the residues are collected by means of appropriate machinery. Three different treatments were tested, compared with a conventional farming technique and an untreated control. Soil samples were also collected to investigate the metal concentrations due to the fall of the pesticide on the soil during the applications.

Pruning wood and soil samples have been collected on the same day and then delivered to the Biomass Lab of Marche Polytechnic University, where sample preparation and analytical analyses were performed.

\section{Treatments in the vineyard}

A randomised block design with 4 replicates was used, and the treatments were assigned to plots using a random number generator (Excel; Microsoft Corp., Redmond, WA, USA). Each plot consisted of seven vines along the row, and the treated rows were spaced each other by an untreated row. Three treatments were tested (Bordeaux mixture, copper hydroxide, laminarin combined with low copper rates) with a total of 11 weekly applications, since the beginning of May to the end of July 2013. The treatments were applied spraying a volume equivalent to $1000 \mathrm{~L} \mathrm{ha}^{-1}$ using a motorized backpack sprayer. Table 1 shows the active ingredients and the application rates employed.

\section{Sampling}

The sampling was carried out in March 2014. Pruning wood samples were taken manually from all the seven plants placed in a plot, forming the plot sample, which was approximately $1.5 \mathrm{~kg}$ and contained 30 to 40 lignified shoots of about $70 \mathrm{~cm}$ length. For each treatment, one sample per each plot was collected. Concerning soil samples, two samples of $1.5 \mathrm{~kg}$ each were collected from the first $2-3 \mathrm{~cm}$ below the plants of the plot. Further soil samples were harvested in a field cultivated with annual crops close to the vineyard.

\section{Sample preparation}

For pruning wood analyses, 30 lignified shoots were chosen randomly from each plot and combined together forming a sample, then divided in two sub-samples of 15 shoots each. Each shoot was cut in pieces of $100 \mathrm{~mm}$ length and submitted to the analytical procedure.

Concerning soil, for each treatment the plot samples were combined together, mixed and then divided into two parts using a riffle box (device recommended by UNI EN 14780:2011; UNI, 2011a). After the division, a part was discarded while the other one was split again using riffle box. The division was repeated until a sample of $50 \mathrm{~g}$ was produced. This procedure was used for each treatment. Each sample was then analysed for minor elements determination.

\section{Analyses performed on samples}

A total of 12 analytical samples of grape shoots were obtained and for each of them a full characterisation was performed determining moisture content, ash content, net calorific value, nitrogen content, chlorine and sulphur contents and also minor elements determination [lead $(\mathrm{Pb})$, mercury $(\mathrm{Hg})$, chromium $(\mathrm{Cr}), \mathrm{Cu}$, manganese $(\mathrm{Mn})$, nickel $(\mathrm{Ni})$, arsenic (As), cadmium (Cd), Zn].

For the moisture content determination, the samples were cut in 10 $\mathrm{cm}$ length pieces. For the other determinations, instead, the samples were stabilised in a forced ventilation oven [mod. M120-VF; MPM Instruments s.r.l., Bernareggio (MB), Italy] at $45 \pm 2{ }^{\circ} \mathrm{C}$ temperature in air atmosphere, then milled with a blade mill (Retsch Mod. SM33$25 \mathrm{~Hz}$ ) and sieved through a $1 \mathrm{~mm}$ mesh.

Concerning soil, 6 samples were obtained in total and the minor elements determination was performed.

For each analysis, both with the shoots and with the soil samples, a duplicate determination was carried out. The values were submitted to variance analysis and the means were separated by Tukey's honest significant difference test, at $\mathrm{P}<0.05$ (Statsoft, Tulsa, OK, USA).

\section{Moisture content determination}

According to UNI EN 14774-2:2010 (UNI, 2010a), the sample was dried at $105 \pm 2{ }^{\circ} \mathrm{C}$ temperature in air atmosphere using forced ventilation oven (mod. M120-VF; MPM Instruments) until constant mass is achieved. Then the percentage moisture was calculated from the loss in mass of the sample.

\section{Ash content determination}

The ash content was determined using a thermo-gravimetric analyser (TGA Leco Mod. 701) according to UNI EN 14775:2010 (UNI, $2010 \mathrm{~b})$. The principle is that the sample is heated in air under controlled conditions of time, sample weight and equipment specifications until a temperature of $550 \pm 10^{\circ} \mathrm{C}$ using a muffle furnace. Then the ash content is determined by calculation from the mass of the remaining residue.

\section{Nitrogen determination}

According to UNI EN 15104:2011 (UNI, 2011b), a known mass of 
sample is burnt in oxygen/carrier gas mixture, under such conditions that it is converted into ash and gaseous products of combustion. Oxides of nitrogen are reduced to nitrogen, and those products of combustion that would interfere with the subsequent gas-analysis procedures are removed. The carbon dioxide, water vapour and nitrogen mass fractions of the gas stream are then determined quantitatively. The combustion, the following separation by a gas chromatograph and the detection of the elements were carried out by an Elemental Analyzer (mod. 2400 Series II CHNS/0 System, Perkin Elmer, Waltham, MA, USA).

\section{Determination of net calorific value}

An isoperibolic calorimeter (mod. C2000 basic; IKA, Staufen, Germany) was used to perform the sample combustion under specific conditions in a bomb calorimeter, according to UNI EN 14918:2010 (UNI, 2010c). The calorimeter was calibrated with benzoic acid standard (IKA Benzoic Acid C723). The net calorific value was determined by a formula indicated in the aforementioned technical standard starting from gross calorific value, water and hydrogen contents of the analytical sample.

\section{Sulphur and chlorine determination}

Sulphur and chlorine contents were measured by decomposition in calorimetric bomb with excess of oxygen and absorption of acid combustion gases in water $\left(10^{-3} \mathrm{~mm}^{3}\right)$, according to UNI EN 15289:2011 (UNI, 2011c). Detection of sulphate and chloride was performed by liquid ion chromatography (mod. 761 COMPACT IC; Metrohm, Herisau, Switzerland). The liquid ion chromatograph was calibrated using a series of standards prepared from a Multielement Standards Solution $1000 \mathrm{mg} \mathrm{dm}^{-3}$ (Fluka).

\section{Minor element determination}

The chemical analysis, carried out according to UNI EN 14918:2010 (UNI, 2010c), provides for the digestion of the biomass sample in a closed container, using a mixture of acids $\left(\mathrm{HNO}_{3} / \mathrm{H}_{2} \mathrm{O}_{2} / \mathrm{HF}\right)$ and microwave oven (mod. Multiwave 3000; Anton Paar, Graz, Austria). The mineralisation product is then analysed by inductively coupled plasma optical emission spectrometry (ICP-OES mod. Optima 2100; PerkinElmer). The spectrometer was calibrated using a series of standards prepared from a Single-Element Standard $1000 \mathrm{mg} \mathrm{dm}^{-3}$ of Perkin Elmer. The elements detected were $\mathrm{Pb}, \mathrm{Hg}, \mathrm{Cr}, \mathrm{Cu}, \mathrm{Mn}, \mathrm{Ni}, \mathrm{As}$, Cd, Zn.

\section{Results and discussion}

The amount of copper in the pruning residues ranges from $7.0 \mathrm{mg}$ $\mathrm{kg}^{-1}$ for the control to $19.2 \mathrm{mg} \mathrm{kg}^{-1}$ for the Bordeaux mixture treatments (Table 2). Treatments with copper hydroxide, laminarin and the farm application did not provide results significantly different from the control test. On the contrary, they are all significantly different from the treatment with Bordeaux mixture.

The determination of copper was performed also in soil and results show the highest amount of copper in soil treated with Bordeaux mixture followed by copper hydroxide. The lowest value is given by the cultivated field near the grapevine, where grape was never cultivated, that is three times lower than the control, exposed in previous years to copper applications (Table 2).

The increase of copper in pruning wood and soils depends on the amount of copper distributed by the treatment of the year. Figure 1 shows how particularly marked is the increase of copper in soil with an increase of copper in treatments: the slope of trend line is 7.2 in soil

Table 1. Details of formulations, application rates and frequencies used in the present study.

\begin{tabular}{|c|c|c|c|c|c|c|}
\hline Active ingredient (\%) & $\begin{array}{l}\text { Commercial } \\
\text { product }\end{array}$ & Company & $\begin{array}{l}\text { Application rate } \\
\text { (g or mL/ha) }\end{array}$ & $\begin{array}{l}\text { Number of } \\
\text { applications }\end{array}$ & $\begin{array}{c}\text { Copper absolute } \\
\text { value (kg/ha) }\end{array}$ & $\begin{array}{l}\text { Year } \\
\text { trial }\end{array}$ \\
\hline Bordeaux mixture (20) & Poltiglia Disperss & Cerexagri Italia S.r.l. (Italy) & 5000 & 11 & 11.0 & 2013 \\
\hline Copper hydroxide (19.2) & Funguran & Certis Europe (Italy) & 2800 & 11 & 5.8 & 2013 \\
\hline $\begin{array}{l}\text { Laminarin + copper } \\
\text { hydroxide/copper oxide (33) }\end{array}$ & Frontiere + Coptrel & $\begin{array}{l}\text { BioAtlantis (Ireland); } \\
\text { Kalosgate (Italy) }\end{array}$ & $1000+500$ & 11 & 1.8 & 2013 \\
\hline $\begin{array}{l}\text { Farm application } \\
\text { (variable percentages): } \\
\text { dimetomorf, mandipropamid, } \\
\text { metalaxyl ametocradin, } \\
\text { metiram, copper hydroxide }\end{array}$ & Unstated & Several & Unstated & 11 & Unstated & 2013 \\
\hline Control & Untreated & - & - & - & - & - \\
\hline
\end{tabular}

Table 2. Comparison between copper distributed and copper registered (mean values) in pruning wood and soil.

\begin{tabular}{lccc} 
Thesis & $\begin{array}{c}\text { Copper absolute value } \\
(\mathrm{kg} / \mathrm{ha})\end{array}$ & $\begin{array}{c}\text { Copper concentration } \\
\text { in the vine pruning (mg/kg) }\end{array}$ & $\begin{array}{c}\text { Copper concentration } \\
\text { in the soil (mg/kg) }\end{array}$ \\
Bordeaux mixture & 11.0 & 19.2 & 113.4 \\
Copper hydroxide & 5.8 & 10.6 & 102.8 \\
\hline Laminarin + copper hydroxide/copper oxide & 1.8 & 8.5 & 81.0 \\
Farm application & 4.3 & 10.9 & 86.3 \\
\hline Control & - & 7.0 & 88.3 \\
\hline
\end{tabular}


and 2.4 in treatments. For a complete characterisation of pruning wood and soil, the content of other heavy metals was determined (Tables 3 and 4). We noticed that also $\mathrm{Zn}$ shows a variable accumulation in pruning wood depending on treatments. In particular, the highest value is $15.5 \mathrm{mg} \mathrm{kg}^{-1}$ given by Bordeaux mixture treatment and is significantly different from the control $\left(5.4 \mathrm{mg} \mathrm{kg}^{-1}\right)$ and the farm application (7.3 $\left.\mathrm{mg} \mathrm{kg}{ }^{-1}\right)$. On the contrary, no difference among treatments was found for $\mathrm{Zn}$ content in the soil.

As stated in the Materials and Methods section, the shoot samples were taken manually, so that no soil contamination occurred. However, the collection of grapevine residues is usually performed using appropriate machinery. In this case, a variable amount of soil could be harvested together with the pruning residues, especially wet soil, increasing the content of copper in pruning wood. In Table 5, a simulation of contamination with different percentages of soil (1-5\%) is proposed taking into account the results of $\mathrm{Cu}$ determination carried out on soil and pruning for each thesis. The simulation concerns the increase of copper content, which reaches a maximum value of $23.9 \mathrm{mg} \mathrm{kg}^{-1}$ when grapevine is treated with Bordeaux mixture and pruning wood is contaminated with $5 \%$ of soil. This indication can be useful to evaluate the possible $\mathrm{Cu}$ content of prunings collected in real operation in comparison with the $\mathrm{Cu}$ content of other biomasses currently employed for energy application.

Pruning samples were characterized also for an energetic application: Table 6 shows mean values of moisture content, ash content, net calorific value, nitrogen, chlorine and sulphur contents. Taking into account these results, the contamination of pruning wood with soil can affect obviously also these parameters, in particular increasing ash content and consequently decreasing the calorific value but to a limited extent.

Data about copper content in biomass for energy use are present in literature. The ISO 17225-1:2014, for instance, indicates for short rota- tion coppice a typical value of $3 \pm 1 \mathrm{mg} \mathrm{kg}^{-1}$, virgin bark materials up to $30 \mathrm{mg} \mathrm{kg}^{-1}$ and logging residues ranging from $1 \mathrm{mg} \mathrm{kg}^{-1}$ till $100 \mathrm{mg} / \mathrm{kg}$ in coniferous wood and till $200 \mathrm{mg} \mathrm{kg}^{-1}$ in broad-leaf wood (ISO, 2014). According to some authors (Riva et al., 2009), industrial wood chips used in power plants can have high $\mathrm{Cu}$ values; the examples of power plants reported show a mean value of $7.0 \pm 11.0 \mathrm{mg} \mathrm{kg}^{-1}$ and maximum value of $108.6 \mathrm{mg} \mathrm{kg}^{-1}$ for the first power plant examined and a mean value of $10.3 \pm 18.2 \mathrm{mg} \mathrm{kg}^{-1}$ and maximum value of $226.0 \mathrm{mg} \mathrm{kg}^{-1}$ for the second power plant.

It is clear that the $\mathrm{Cu}$ values of grapevine pruning wood under this study fall within the ranges of biomass for energy use found in literature, especially the biomass employed in large-scale boilers.

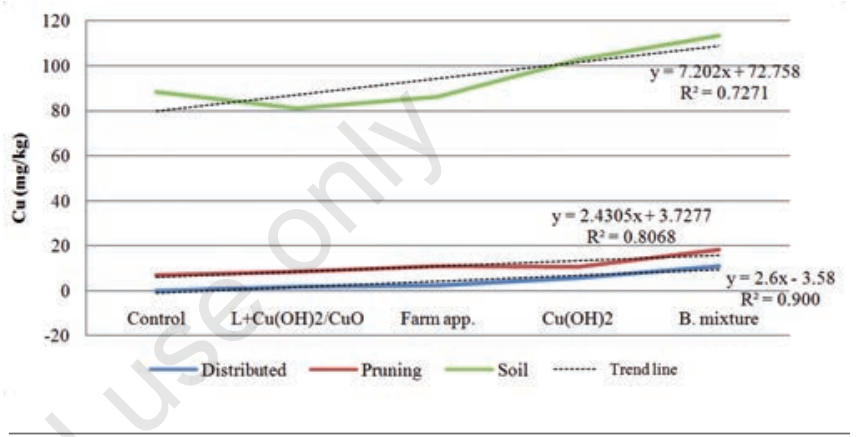

Figure 1. Correlation between copper distributed with treatments and copper found in pruning wood and soil, with related trend lines. $\mathrm{L}+\mathrm{Cu}(\mathrm{OH})_{2} \mathrm{CuO}^{-1}=$ Laminarin + copper hydroxide/copper oxide; Farm app. $=$ Farm application; $\mathrm{Cu}(\mathrm{OH})_{2}=$ Copper hydroxide; $B$. mixture $=$ Bourdeaux mixture.

Table 3. Amount of heavy metals in the pruning wood of the vine exposed to the different treatments.

\begin{tabular}{|c|c|c|c|c|c|c|c|c|c|}
\hline Treatment & As (mg/kg) & Cd (mg/kg) & $\operatorname{Cr}(\mathrm{mg} / \mathrm{kg})$ & $\mathrm{Cu}(\mathrm{mg} / \mathrm{kg})$ & Hg (mg/kg) & Mn (mg/kg) & Ni (mg/kg) & $\mathrm{Pb}(\mathrm{mg} / \mathrm{kg})$ & Zn (mg/kg) \\
\hline Bordeaux mixture & $<0.67^{\mathrm{a}}$ & $0.1 \pm 0.1^{\mathrm{a}}$ & $0.2 \pm 0.3^{\mathrm{a}}$ & $18.1 \pm 3.6^{\mathrm{a}}$ & $<0.01^{\mathrm{a}}$ & $34.3 \pm 20.9^{a}$ & $1.0 \pm 0.7^{\mathrm{a}}$ & $<0.36^{\mathrm{a}}$ & $15.5 \pm 3.7^{\mathrm{b}}$ \\
\hline Copper hydroxide & $<0.67^{\mathrm{a}}$ & $0.3 \pm 0.2^{\mathrm{a}}$ & $0.2 \pm 0.2^{\mathrm{a}}$ & $10.6 \pm 1.6^{b}$ & $<0.01^{\mathrm{a}}$ & $47.9 \pm 10.4^{\mathrm{a}}$ & $1.8 \pm 1.4^{\mathrm{a}}$ & $<0.36^{\mathrm{a}}$ & $10.7 \pm 1.6^{\mathrm{ab}}$ \\
\hline $\begin{array}{l}\text { Laminarin + } \\
\text { copper hydroxide/ } \\
\text { copper oxide }\end{array}$ & $<0.67^{\mathrm{a}}$ & $0.3 \pm 0.1^{\mathrm{a}}$ & $0.4 \pm 0.3^{\mathrm{a}}$ & $8.5 \pm 0.5^{b}$ & $<0.01^{\mathrm{a}}$ & $36.5 \pm 2.9^{\mathrm{a}}$ & $1.8 \pm 0.8^{\mathrm{a}}$ & $<0.36^{\mathrm{a}}$ & $9.9 \pm 5.1^{\mathrm{ab}}$ \\
\hline Farm application & $<0.67^{a}$ & $0.3 \pm 0.1^{\mathrm{a}}$ & $0.2 \pm 0.1^{\mathrm{a}}$ & $10.9 \pm 2.5^{b}$ & $<0.01^{\mathrm{a}}$ & $30.6 \pm 4.9^{\mathrm{a}}$ & $1.6 \pm 0.2^{\mathrm{a}}$ & $<0.36^{a}$ & $7.3 \pm 1.6^{a}$ \\
\hline Control & $<0.67^{\mathrm{a}}$ & $0.3 \pm 0.1^{\mathrm{a}}$ & $0.2 \pm 0.1^{\mathrm{a}}$ & $7.0 \pm 0.6^{\mathrm{b}}$ & $<0.01^{\mathrm{a}}$ & $51.2 \pm 4.8^{\mathrm{a}}$ & $1.5 \pm 0.3^{\mathrm{a}}$ & $<0.36^{\mathrm{a}}$ & $5.4 \pm 3.6^{\mathrm{a}}$ \\
\hline
\end{tabular}

As, arsenic; Cd, cadmium; Cr, chromium; Cu, copper; Hg, mercury; Mn, manganese; Ni, nickel; Pb, lead; Zn, zinc. a,bValues followed by different letters in the same column are significantly different according to Tukey's honest significant difference test $(\mathrm{P}<0.05)$.

Table 4. Amount of heavy metals in the soils of the different treatments.

\begin{tabular}{|c|c|c|c|c|c|c|c|c|c|}
\hline Treatment & As (mg/kg) & $\mathrm{Cd}(\mathrm{mg} / \mathrm{kg})$ & Cr (mg/kg) & $\mathrm{Cu}(\mathrm{mg} / \mathrm{kg})$ & Hg (mg/kg) & Mn (mg/kg) & Ni (mg/kg) & $\mathrm{Pb}(\mathrm{mg} / \mathrm{kg})$ & Zn (mg/kg) \\
\hline Bordeaux mixture & $9.7 \pm 0.2^{\mathrm{a}}$ & $0.2 \pm 0.1^{\mathrm{a}}$ & $87.2 \pm 3.1^{\mathrm{a}}$ & $113.4 \pm 5.8^{a}$ & $<0.01^{\mathrm{a}}$ & $842.5 \pm 23.2^{\mathrm{a}}$ & $64.2 \pm 8.5^{\mathrm{a}}$ & $32.6 \pm 6.5^{\mathrm{a}}$ & $59.6 \pm 7.2^{\mathrm{a}}$ \\
\hline Copper hydroxide & $10.1 \pm 0.3^{a}$ & $0.1 \pm 0.1^{\mathrm{a}}$ & $95.3 \pm 2.8^{\mathrm{a}}$ & $102.8 \pm 4.4^{\mathrm{a}}$ & $<0.01^{\mathrm{a}}$ & $843.8 \pm 17.7^{\mathrm{a}}$ & $68.6 \pm 7.4^{\mathrm{a}}$ & $33.7 \pm 6.2^{\mathrm{a}}$ & $68.1 \pm 8.3^{\mathrm{a}}$ \\
\hline $\begin{array}{l}\text { Laminarin + } \\
\text { copper hydroxide/ } \\
\text { copper oxide }\end{array}$ & $9.6 \pm 0.2^{\mathrm{a}}$ & $0.2 \pm 0.1^{\mathrm{a}}$ & $89.5 \pm 2.5^{\mathrm{a}}$ & $81.0 \pm 2.1^{\mathrm{b}}$ & $<0.01^{\mathrm{a}}$ & $827.9 \pm 13.6^{\mathrm{a}}$ & $65.0 \pm 8.4^{\mathrm{a}}$ & $29.2 \pm 5.6^{\mathrm{a}}$ & $59.5 \pm 6.8^{\mathrm{a}}$ \\
\hline Farm application & $10.8 \pm 0.2^{\mathrm{a}}$ & $0.1 \pm 0.1^{\mathrm{a}}$ & $98.0 \pm 3.4^{\mathrm{a}}$ & $86.3 \pm 3.5^{b}$ & $<0.01^{\mathrm{a}}$ & $799.1 \pm 14.6^{\text {ab }}$ & $73.7 \pm 9.2^{\mathrm{a}}$ & $39.0 \pm 7.1^{\mathrm{a}}$ & $68.4 \pm 6.9^{\mathrm{a}}$ \\
\hline $\begin{array}{l}\text { Cultivated field } \\
\text { out of vineyard }\end{array}$ & $6.3 \pm 0.1^{\mathrm{a}}$ & $0.1 \pm 0.1^{\mathrm{a}}$ & $74.0 \pm 3.2^{\mathrm{b}}$ & $28.1 \pm 0.8^{c}$ & $<0.01^{\mathrm{a}}$ & $709.6 \pm 16.5^{\mathrm{ab}}$ & $51.0 \pm 8.0^{\mathrm{a}}$ & $24.1 \pm 6.2^{\mathrm{a}}$ & $47.9 \pm 6.1^{\mathrm{a}}$ \\
\hline Control & $9.2 \pm 0.2^{\mathrm{a}}$ & $0.1 \pm 0.1^{\mathrm{a}}$ & $91.3 \pm 2.9^{a}$ & $88.3 \pm 2.6^{b}$ & $<0.01^{\mathrm{a}}$ & $799.8 \pm 21.4^{b}$ & $67.2 \pm 7.4^{\mathrm{a}}$ & $32.6 \pm 7.0^{\mathrm{a}}$ & $64.7 \pm 7.0^{\mathrm{a}}$ \\
\hline
\end{tabular}

As, arsenic; Cd, cadmium; Cr, chromium; Cu, copper; Hg, mercury; Mn, manganese; Ni, nickel; Pb, lead; Zn, zinc. ${ }^{\text {acc } V a l u e s ~ f o l l o w e d ~ b y ~ d i f f e r e n t ~ l e t t e r s ~ i n ~ t h e ~ s a m e ~ c o l u m n ~ a r e ~ s i g n i f i c a n t l y ~ d i f f e r e n t ~ a c c o r d i n g ~ t o ~ T u k e y ' s ~}$ honest significant difference test $(\mathrm{P}<0.05)$. 
Table 5. Copper variation during the simulation of different percentages of soil contamination on pruning residues.

\begin{tabular}{|c|c|c|c|c|c|c|c|}
\hline Thesis & $\begin{array}{l}\text { Copper in pruning } \\
\text { wood ( } \mathrm{mg} / \mathrm{kg} \text { ) }\end{array}$ & $\begin{array}{c}\text { Copper in soil } \\
(\mathrm{mg} / \mathrm{kg})\end{array}$ & & rent & $\begin{array}{l}\text { in pri } \\
\text { conta }\end{array}$ & $\begin{array}{l}\text { at } \\
\text { ion }(\end{array}$ & \\
\hline & & & $1 \%$ & $2 \%$ & $3 \%$ & $4 \%$ & $5 \%$ \\
\hline Bordeaux mixture & 19.2 & 113.4 & 20.1 & 21.1 & 22.0 & 23.0 & 23.9 \\
\hline Copper hydroxide & 10.6 & 102.8 & 11.5 & 12.4 & 13.4 & 14.3 & 15.2 \\
\hline Laminarin + copper hydroxide/copper oxide & 8.5 & 81.0 & 9.2 & 10.0 & 10.7 & 11.4 & 12.1 \\
\hline Farm application & 10.9 & 86.3 & 11.7 & 12.4 & 13.2 & 13.9 & 14.7 \\
\hline Control & 7.0 & 88.3 & 7.8 & 8.6 & 9.4 & 10.3 & 11.1 \\
\hline
\end{tabular}

Table 6. Energetic characterisation of pruning wood.

\begin{tabular}{lcccccc} 
Thesis & Moisture (\% a.r.) & Ash (\% d.m.) & NCV (MJ/kg d.m.) & N (\% d.m.) & Cl (\% d.m.) & S (\% d.m.) \\
Bordeaux mixture & 40.6 & 3.3 & 17.669 & 0.6 & 0.03 & 0.04 \\
Copper hydroxide & 41.8 & 3.3 & 17.607 & 0.7 & 0.02 & 0.03 \\
\hline Laminarin + copper hydroxide/copper oxide & 41.1 & 3.2 & 17.565 & 0.6 & 0.01 & 0.02 \\
Farm application & 40.3 & 3.1 & 17.668 & 0.6 & 0.01 & 0.03 \\
\hline Control & 42.7 & 3.3 & 17.779 & 0.5 & 0.02 & 0.04 \\
Overall average & 41.4 & 3.3 & 17.658 & 0.6 & 0.02 & 0.03 \\
\hline
\end{tabular}

$\mathrm{NCV}$, net calorific value; $\mathrm{N}$, nitrogen; $\mathrm{Cl}$, chlorine; S, sulphur; a.r., as received; d.m., dry matter.

\section{Conclusions}

In the present study an evaluation of vineyard pruning wood characteristics for energy use was performed. Since vineyards are exposed to treatments based on $\mathrm{Cu}$ and $\mathrm{Zn}$, those metals last in wood residues during the pruning and accumulate in the soil.

The grapevine residues free of impurities that we collected during this study have typical values of copper in pruning wood varying from $8.5 \mathrm{mg} \mathrm{kg}^{-1}$ when treated with low Cu product until $19.2 \mathrm{mg} \mathrm{kg}^{-1}$ when treated with high $\mathrm{Cu}$ product. Zinc varies from $9.9 \mathrm{mg} \mathrm{kg}^{-1}$ (low $\mathrm{Cu}$ product) until $15.5 \mathrm{mg} \mathrm{kg}^{-1}$ (high Cu product). No significant variation was stated for the other minor elements. Concerning energetic parameters, the typical values are the overall averages shown in Table 6, since the treatments did not entail variations.

We observed that contaminations of pruning residues with soil could increase the amount of copper. More in detail, every percentage point of soil that winds up on pruning wood involves an increase of $1 \mathrm{mg}$ of $\mathrm{Cu}$ every kg of biomass. For this reason, we recommend to use appropriate systems for the harvest of grapevine residues, particularly mechanical systems that avoid soil lifting. On the market are yet available specific machineries for the correct collection of vineyard pruning residues for energy application. Some of these harvesters produce bales while others produce short sticks limiting soil contamination and preserving biomass quality.

In any case, the Cu values detected in pruning wood are in line with those found in literature. In particular, the European Standard about general requirements of solid biofuels establishes that typical $\mathrm{Cu}$ values of different biomasses for energy use can vary and be higher than the values found in this study. Moreover, it was pointed out that industrial chips used in power plants could have up to $226 \mathrm{mg} \mathrm{kg}^{-1} \mathrm{Cu}$ value. For this reason, we suggest to use pruning residues preferably in largescale power plants with appropriate emission filters instead of smallscale domestic boilers.

\section{References}

Bacenetti J., Duca D., Negri M., Fusi A., Fiala M. 2015. Mitigation strategies in the agro-food sector: the anaerobic digestion of tomato purée by-products. An Italian case study. Sci. Total Environ. 526:88-97.

De Noord M., Beurskens L.W.M., De Vries H.J. 2004. Potentials and costs for renewable electricity production. A data overview. ECN-C03-006. Available from: http://www.ecn.nl/docs/library/report/ 2003/c03006.pdf

Diamantidis N.D., Koukios E.G. 2000. Agricultural crops and residues as feedstocks for non-food products in Western Europe. Ind. Crops Prod. 11:97-106.

Doornbosch R., Steenblik R. 2007. Biofuels: is the cure worse than the disease? SG/SD/RT(2007)3/REV1. Organisation for economic cooperation and development (OECD), Paris, France. Available from: http://www.oecd.org/sd-roundtable/39411732.pdf

Ericsson K., Nilsson L.J., 2006. Assessment of the potential biomass supply in Europe using a resource-focused approach. Biomass Bioener. 30:1-15.

European Commission. 2009. Directive 2009/28/EC of the European Parliament and of the Council of 23 April 2009 on the promotion of the use of energy from renewable sources and amending and subsequently repealing Directives 2001/77/EC and 2003/30/EC. In: Official Journal, L 140, 5/6/2009, pp 16-62.

European Commission. 2014. National action plans. Available from: http://ec.europa.eu/energy/renewables/action_plan_en.htm Accessed: August 2014.

EUROSTAT. 2014. European statistics database. Available from: http://ec.europa.eu/eurostat/data/database Accessed: August 2014.

Gallagher E. 2008. The Gallagher review of the indirect effects of biofuels production. Renewable Fuels Agency, St Leonards-on-Sea, UK.

ISO (International Standard Organisation). 2014. ISO 17225-1:2014 
Solid biofuels - Fuel specifications and classes - Part 1: General requirements. International Standard Organisation, Geneva, Switzerland.

ISTAT (Istituto Nazionale di Statistica). 2014. Superficie e produzione. http://dati.istat.it/Index.aspx?DataSetCode=DCSP_COLTIVAZ\&Lan $\mathrm{g}=$ Accessed: August 2014

Italian Regulation. 1997. Decreto Legislativo 5 febbraio 1997, n. 22. Attuazione delle direttive 91/156/CEE sui rifiuti, 91/689/CEE sui rifiuti pericolosi e 94/62/CE sugli imballaggi e sui rifiuti di imballaggio. In: G.U. no. 38, 15/02/1997 - Suppl. Ord. no. 3.

Italian Regulation. 2006. Decreto Legislativo 3 aprile 2006, n. 152. Norme in materia ambientale. In: G.U. no. 88, 14/04/2006 - Suppl. Ord. no. 96.

Juang K.W., Lee Y.I., Lai H.Y., Wang C.H., Chen B.C., 2012. Copper accumulation, translocation, and toxic effects in grapevine cuttings. Environ. Sci Pollut. Res. Int. 19:1315-22.

Komárek M., adková E., Chrastný V., Bordas F., Bollinger J.C. 2010. Contamination of vineyard soils with fungicides: a review of environmental and toxicological aspects. Environ. Int. 36:138-51.

Koukios E.G. 1998. Agriculture as a source of biomass in Western Europe. Report for Biomass for Greenhouse Gas Emission REDuction (BRED) Project. Bioresource Technology Unit, National Technical University of Athens, Athens, Greece.

Lai H.Y., Juang K.W., Chen B.-C. 2010. Copper concentrations in grapevines and vineyard soils in central Taiwan. Soil Sci. Plant Nutr. 56:601-6.

McDonald J.D., Zielinska B., Fujita E.M., Sagebiel J.C., Chow J.C., Watson J. 2000. Fine particle and gaseous emission rates from residential wood combustion. Environ. Sci. Technol. 34:2080-91.

Monforti F., Bódis K., Scarlat N., Dallemand J.F. 2013. The possible contribution of agricultural crop residues to renewable energy targets in Europe: a spatially explicit study. Renew. Sustain. Energy Rev. 19:666-77.

Motola V., Colonna N., Alfano V., Gaeta M., Sasso S., De Luca V., De Angelis C., Soda A., Braccio G. 2009. Censimento potenziale energetico biomasse, metodo indagine, atlante Biomasse su WEB-GIS. Report RSE/2009/167. ENEA, Roma, Italy. Available from: http://old.enea.it/attivita_ricerca/energia/sistema_elettrico/Censi mento_biomasse/RSE167.pdf

Nikolaou A., Remrova M., Jeliazkov I. 2003. Lot 5: Bioenergy's role in the EU Energy Market. Biomass Availability in Europe. Available from: https://np-net.pbworks.com/f/CRES+(2003)+Biomass+availability+in+EU.pdf

Obernberger I., Brunner T., Bärnthaler G., 2006. Chemical properties of solid biofuels-significance and impact. Biomass Bioener. 30:973-82.

Picchi G., Silvestri S., Cristoforetti A. 2013. Vineyard residues as a fuel for domestic boilers in Trento Province (Italy): comparison to wood chips and means of polluting emissions control. Fuel 113:43-9.

Provenzano M.R., El Bilali H., Simeone V., Baser N., Mondelli D., Cesari G. 2010. Copper contents in grapes and wines from a Mediterranean organic vineyard. Food Chem. 122:1338-43.

Ribolzi O., Valles V., Gomez L., Voltz M. 2002. Speciation and origin of particulate copper in runoff water from a Mediterranean vineyard catchment. Environ. Pollut. 117:261-71.

Riva G., Foppa Pedretti E., Toscano G. 2009. Use of the contro chart to monitor the biomass quality in power plants. pp 1185-1190 in XXXIII CIOSTA-CIGR V Conference on Technology and management to ensure sustainable agriculture, agro-systems, forestry and safety, Reggio Calabria, Italy.

Romanazzi G., Mancini V., Feliziani E., Servili A., Nardi S., Flamini L. 2014. Effectiveness of alternative compounds in the control of grapevine downy mildew. pp 111-112 in Proc. GDPM2014, June 30 th to July 4th, Vitoria-Gasteiz, Spain.

Romeu-Moreno A., Mas A. 1999. Effects of copper exposure in tissue cultured Vitis vinifera. J. Agricult. Food Chem. 47:2519-22.

Ruyters S., Salaets P., Oorts K., Smolders E. 2013. Copper toxicity in soils under established vineyards in Europe: A survey. Sci. Total Environ. 443:470-7.

Searchinger T., Heimlich R., Houghton R.A., Dong F., Elobeid A., Fabiosa J., Tokgoz S., Hayes D., Yu T.H. 2008. Use of U.S. croplands for biofuels increases greenhouse gases through emissions from land-use change. Science 319:1238-40.

Siemons R.V., van den Berg D., Mc Chesney I., Whiteley M., Nikolaou N. 2004. Bio-energy's role in the EU energy market. A view of developments until 2020. Report of the European Commission. BTG biomass technology group BV, Enschede, The Netherlands.

Szabò M., Jagher-Waldau A., Monforti-Ferrario F., Scarlat N., Bloem H., Quicheron M., Huld T., Ossenbrink H. 2011. Technical Assesment of the Renewable Energy Action Plans. Available from: https://ec.europa.eu/jrc/sites/default/files/jrc_reference_report_20 11_reap.pdf

Toscano G., Riva G., Duca D., Pedretti E.F., Corinaldesi F., Rossini G. 2013. Analysis of the characteristics of the residues of the wine production chain finalized to their industrial and energy recovery. Biomass Bioenerg. 55:260-7.

UNI (Ente Italiano di Normazione). 2010a. UNI EN 14774-2:2010. Biocombustibili solidi - Determinazione dell'umidità - Metodo di essiccazione in stufa - Parte 2: Umidità totale - Metodo semplificato. UNI, Milano-Roma, Italy.

UNI (Ente Italiano di Normazione). 2010b. UNI EN 14775:2010. Biocombustibili solidi - Determinazione del contenuto di ceneri. UNI, Milano-Roma, Italy.

UNI (Ente Italiano di Normazione). 2010c. UNI UNI EN 14918:2010. Biocombustibili solidi - Determinazione del potere calorifico. UNI, Milano-Roma, Italy.

UNI (Ente Italiano di Normazione). 2011a. UNI EN 14780:2011. Biocombustibili solidi - Preparazione del campione. UNI, MilanoRoma, Italy.

UNI (Ente Italiano di Normazione). 2011b. UNI EN 15104:2011. Biocombustibili solidi - Determinazione del contenuto totale di carbonio, idrogeno e azoto - Metodi strumentali. UNI, Milano-Roma, Italy.

UNI (Ente Italiano di Normazione). 2011c. UNI EN 15289:2011. Biocombustibili solidi - Determinazione del contenuto totale di zolfo e cloro. UNI, Milano-Roma, Italy. 